\title{
The Great Transformation of Central Eastern Europe: Success and Disappointment
}

\author{
János Kornai \\ Harvard University, Collegium Budapest and Central European University
}

\section{Introduction}

The paper examines eight particular countries that became members of the European Union in 2004. These are the Czech Republic, Estonia, Poland, Latvia, Lithuania, Hungary, Slovakia, and Slovenia. I will take the liberty of referring collectively to these countries as Central Eastern Europe or the Central Eastern European region, though of course this is a bit geographically imprecise. As I am writing these lines, the European Union is undergoing trying times and it is impossible to guess what the future will bring. Whatever influence the eventual fate of the European Union will exert on the eight countries under consideration is a distinct issue from the topic of this study. On the other hand, it may be worthwhile to take a look at this region separately, since the status of each country was subjected to microscopic examination by various bodies of the $\mathrm{EU}$ prior to accession. The memberships may be seen as certificates, which are supposed to attest to the fact that these countries boast both democratic political systems and functioning market economies.

After 1990, the Communist Party's dictatorship has come to an end in ten countries, namely in the Soviet Union and in countries that were in close military and economic alliance with it such as Bulgaria, Czechoslovakia, Poland, Hungary, Mongolia, the German Democratic Republic and Romania; additionally, in the former Yugoslavia and Albania, which already had rather loose ties with the Soviet Union at that time. I would not even dare to attempt to review this entire area in this paper, if for no other reason than, - that primarily from the standpoint of their political structures - there are huge differences among the individual countries. From this standpoint, the eight countries comprising the subject of my analysis are rather homogenous. So although they share a number of important characteristics with this larger group, the set of countries I am focusing cannot be viewed as a "representative sample" of this wider class. Delineating the topics of my analysis I made a deliberate choice: I wanted to focus on the region where reforms were most consistent and farreaching. Regarding the eight new member states, I solely confine myself to the discussion of their similarities, and I do not deal with the description and the explication of the considerable differences that exist between them.

Let us jump back in time a couple of decades and recall the mood and expectations of the people living in this region, who opposed to Communist system.

\footnotetext{
Presidential Address, delivered at the 14th World Congress of the International Economic Association in Marrakech, Morocco on August 29, 2005.

I am grateful to Zdenek Kudrna, who helped my work by careful data collection and making useful comments, to Philippe Aghion, Zsuzsa Dániel, Jean-Paul Fitoussi, Stephan Haggard and Gérard Roland, who commented on the first version of the manuscript, as well as to Tamar Gendler, Noémi Peter, Katalin N. Szabó, László Szimonisz, László Tóth, István Gy. Tóth and János Varga, who assisted in the underlying research and in editing and translating the manuscript.
} 
At that time, they felt it a hopeless daydream that within the foreseeable future their countries would become democratic market economies. Today however, though this has become a reality, many are disappointed and bitter.

A number of analyses - both official and scholarly - have already been published on this topic. They contain important statistical data revealing a great deal about the current political and economic situation of each of the countries under consideration, as well as their relative standing. Noteworthy studies have also appeared that offer causal analyses of these results ${ }^{1}$. I will not attempt to summarize this rich and valuable body of literature, nor is my aim to confirm or refute these prior analyses. Instead, I hope to complement them by focusing on aspects of the transformation that have not yet received sufficient attention.

In the discussion below, I will take special care to separate my description of the facts from the normative judgments that I will make about those facts, and from the ordering of values which underlies those judgments. Care about such matters is important both for understanding both the data, and for locating properly where points of disagreement lie.

The paper is divided into two parts: in the first, I will examine the transformation historically; in the second, I will consider it from the perspective of the contemporary man's everyday life.

\section{In the context of world history}

First of all, we are going to look at long historical periods. The historical units in question will be relatively large - decades, even centuries. And though the focus will remain on Central Eastern Europe, I will be looking at other regions of the world for purposes of comparison. The methodology of the first section is concisely epitomized by the title of Charles Tilly's (1984) book: "Big structures, large processes, huge comparisons."

\subsection{The main direction of economic transformation in Western civilization}

During the last millennium various capitalist forms of the economy have gained more and more ground in Western civilization. ${ }^{2}$ Traces of this had already appeared in antiquity and formed important building blocks of medieval society from the very beginning. The characteristic institutions of capitalism — private property, hired labor, market-type buying and selling, a credit system, and a legal system protecting the sanctity of private property and contracts - evolved in various countries at various speed. Institutional transformation has been inseparably associated with such profound processes as urbanization, industrialization and commercialization. All the above comprise what is known as the capitalist economy. ${ }^{3}$

There is no agreement among historians as to when the Middle Ages ended and when the Modern Age began. ${ }^{4}$ Moreover, there is not even any agreement on the subject of whether any criteria could be provided to separate the end from the beginning, and if so, whether it should be sought in the economic, political, or religious-ideological-intellectual sphere. However, there is a fairly wide agreement about the fact that in what most historians refer to as the Modern Age, or modernity, it is the capitalist economy which is dominant. The economy is in a constant state of motion and transformation. Accordingly, this transformation has a characteristic main direction, namely, the expansion of the capitalist economic order. Expansion is accompanied by deepening of its effects. 
The spread of capitalism has been slow and complicated. In some cases capitalist and pre-capitalist forms co-exist in a stable fashion. In others, there is rapid acceleration followed by stagnation, even reversal. And when acceleration does occur, its causes may be numerous: political revolution, the appearance of a great statesman with a propensity for innovation, new regulations created by a political group, geographical discoveries (such as the conquest of the New World), or the introduction of great inventions (such as the steam engine, railroads, or application of electricity).

Influenced by Marx's theory, the Communist parties prior to coming into power endorsed the principle that a main direction of economic history did indeed exist. This, however, according to the Marxists, points beyond capitalism. The Communist parties considered it fundamental to create a system superseding capitalism. They provided explicit criteria for comparing the two systems: growth in labor productivity and its concomitants, in particular, rates of production, and increases in standard of living.

The monumental verification attempt, which eventually failed, lasted for over seventy years in the Soviet Union and for about forty years in Eastern Europe. There were moments in the race between the socialist and capitalist systems when even among the adherents of the capitalist system some became unsure. Remember that in the years following the Great Depression of 1929 most developed countries went into a deep recession while the first Five Year Plan of the Soviet Union realized spectacular results and produced a high growth rate. And remember that when the first Sputnik was successfully launched, many took this to be the dawning of an age of Soviet technical and military superiority. However, if we measure these events on the scale of long decades and look at the entire period of the existence of the socialist system, one thing is definitely a proven fact: capitalism is more productive, more innovative, with a faster growth rate that produced a higher increase in the standard of living. Table 1 provides a comparison between the growth of socialist and capitalist countries during the last four decades before the collapse. Socialist countries are represented by the Soviet Union, as well as by three of the new EUmembers (Czechoslovakia, Poland and Hungary), whereas the capitalist economy is represented by 13 old EU-members. ${ }^{5}$ The table clearly indicates the growing superiority of the capitalist economy.

Note that in saying this, I am certainly not claiming that we have come to the end of history, nor am I suggesting that capitalism will never be superseded at some point in the future. I do not undertake prophesy. However, it is an irrefutable fact that the existing (or, heretofore existing) socialism lost the race against the existing (or, heretofore existing) capitalism. This is not a value judgment; it is an observable, statistically accountable fact: until now, in the world of Western civilization, the main trend of history has pointed toward the direction of the expansion of capitalism.

The painful and bitter series of actions in the creation of the socialist system was a deviation from the main direction. Now, the countries of the Central Eastern European region have turned around. After backing out of the dead-end street fifteen years ago, we are now completely on the main path.

While this is a value-free statement of fact, the closely associated question of whether this is to be considered a success can be answered only by offering a valuebased judgment. I will return to this later.

Higher productivity and increased growth rates did not begin immediately: the transition to the new economic system started out with a serious slow-down. By now, however, the growth has speeded up. In six out of the eight countries the 
growth rate during the past ten years was significantly higher than in the decade prior to 1990 as seen in Table 2. During the period between 1995 and 2003, per capita GDP in the region where the eight new members are located, along with labor productivity (GDP per employee) and per capita real consumption grew at a much higher rate than in other countries of the European Union as shown in Table 3. The difference is especially impressive in labor productivity; its pace among the new members is more than four times than that of the old members.

Let us be careful with the interpretation of these numbers. At this point in our analysis, we want to compare a system with another system, the permanent attributes of one system with the permanent attributes of the other. Applying the historical scale, only a very brief period of time has gone by. We do not know how much of the rapid growth can be traced to the new order's utilization of formerly hidden reserves not exploited by previous inefficient system. The high rate of growth could be partially attributed to the fact that deep recessions are usually followed by rapid upswings. These obvious, easily mobilized reserves will sooner or later be depleted. It would be misleading to draw final conclusions based on the numbers of a single decade. We need long time before the superiority of the new capitalist system could be proven unequivocally and with a fully convincing force. However, if we were to judge based on past experience, we can be optimistic regarding the growth potential of the new system.

\subsection{The main direction of political transformation in Western civilization}

During the past few centuries the main direction of transformation in Western civilization has been felt not only in the economic but also in the political sphere. Alongside the almost unlimited monarchical power assented to by the churches could be found limited precursors of democracy, among them the various self-governing organizations and forms of representation available to the urban middle-classes, and certain of the church institutions. In some countries, laws curtailing the absolute power of the monarchy were enacted and the first elements of parliamentarianism "enlightened" versions of the monarchy - appeared. Later, an ever increasing range of rights were bestowed on parliament and the right to vote was extended to an ever increasing portion of the population. Institutions of modern parliamentary democracy were gradually formed and strengthened. Over the centuries, more and more countries have become democracies.

Closely tied to the changes of the political structure has been the fact that an ever increasing percentage of the population has been able to exercise their basic human rights, freedom of speech, freedom of association and the right to participate in the decision making process. Discrimination based on various criteria such as gender, race, religious affiliation, etc. is being progressively eliminated.

A number of authors have described the "waves" of democratization that have occurred during the second half of the $20^{\text {th }}$ century. ${ }^{6}$ The third swept Southern Europe, Latin America, and Asia from the 1970s through 1980s ; the fourth is the one we have just witnessed following the collapse of the Soviet and Eastern European communist regimes. ${ }^{7}$

Of course, the specific path of history differs from country to country. As I noted above, progress towards democracy may come to a standstill or reverse its direction. But even an earthshaking change like Hitler's rise to power, which led to the destruction of many millions of people and a cataclysm of immeasurable proportions appears to have been - on a historical scale - a short-lived diversion from the main path. and the main direction eventually wins. 
From the point of view of our topic, we must scrutinize the Communist party's ascension to power. This is inextricably intertwined with the other "deviation" just discussed, namely that in countries where the Communists came to power they derailed the economic system off its main track, and forced their socialist program on society. That imposition was made possible by their seizure of political power and the creation of totalitarian dictatorship.

During the past fifteen years, the Central Eastern European region has been successful in backing out of the dead end of the political sphere and moving again in the main direction, similarly to the movement in the economic sphere. Though there have been many discussions concerning the strength of the prevailing democratic order and the extent it satisfies various requirements, for purposes of the present analysis, it should suffice to apply the "minimalist" criteria of democracy. A "democratic minimum" is fulfilled if a government of a country comes into power as a result of a competition for the votes of the citizens and can be removed from office within the framework of a civilized process ${ }^{8}$ without a palace putsch, military coup, assassination, or revolution. Elections held on the basis of political competition, together with the guarantee of other civil rights, create the procedures and mechanisms for officials to be removed and leadership to be transferred to others. This assures the elimination of tyrannical rule. It is true, however, that beyond these minimum criteria one might require the fulfillment of various additional criteria within a thriving, consolidated democracy. Let us not forget, though, that to the person who has just recently been freed from the clutches of tyranny, even the democratic minimum means a great deal. In the research presented herein, we employed the following test: the process of rising to power meets the democratic minimum, if as a result of the elections that have occurred since 1989 the incumbent governments had been replaced at least twice. The CEE-region easily passes the numerical threshold established in the test: In each of the eight countries there have been at least three such elections where the incumbent government was replaced though a civilized election process that resulted in the coming into office of a newly and democratically elected government. As Table 4 illustrates, 30 out of the 38 elections that concluded the competitions of the political parties resulted in the replacement of the incumbent governing political power, party or coalition.

The two categories of historical changes discussed so far are asymmetrically interconnected. The appearance of a capitalist economic system does not automatically guarantee the emergence of a democracy; there were and are countries whose economic system is capitalist, but whose political structure does not fulfill the minimum requirements for a democracy. Indeed, a capitalist economic system can be compatible with partly, or even wholly dictatorial political regimes. But this independence does not hold in the other direction: democracy can only become a permanent form of political governance where the economy operates within a capitalist system. There is no democracy without capitalism. ${ }^{9}$

We are now in a position to recognize the following value-free historical fact: the new political structure of the Central Eastern European region reflects the main direction of historical progress over the last two millennia. Whether this is to be lauded, and if so why, is a question we will return to later.

The idea that the large-scale political and economic changes have certain main directions is acknowledged by some schools of history and other social sciences and denied by others. I have tried to distance myself from rigid and one-sided versions of this idea; I see no evidence that some kind of simple, linear and at all times 
unidirectional movement takes place. I have been explicit that, regarding both the economic and the political spheres, there may be stagnation and backward movement, as well as the permanent co-existence of various economic and political systems. ${ }^{10}$ But these acknowledgments do not undercut one of the main ideas of the current study, which is that it is possible to observe the main direction of the changes in the worlds of both economic and political institutions. The transformation that took place after the collapse of the Soviet and the Eastern European regimes provides a new and important supplement to the debate about the main directions.

\subsection{Six characteristics}

As a starting point for further analysis, I would like to summarize the six most important characteristics of the transformation that has taken place in the Central Eastern European region during the past fifteen years.

1. and 2. The changes follow the main directions of development of Western civilization: in the economic sphere in the direction of the capitalist economic system, and in the political field in the direction of democracy.

3. There was a complete transformation, parallel in all spheres: in the economy, in the political structure, in the world of political ideology, in the legal system and in the stratification of society

4. The transformation was non-violent.

5. The process of transformation took place under peaceful circumstances. It was not preceded by war. The changes were not forced upon society as a result of foreign military occupation.

6. The transformation took place with incredible speed, within a time-frame of ten to fifteen years.

This has not been the first "great transformation" in world history, to borrow an expression from Karl Polányi. ${ }^{11} \mathrm{He}$ also emphasized the fact, which we already know from the study of world history, that other "great transformations" have taken place at different times and in different regions of the world, sweeping transformations from one type of formation into another. Of the above listed six characteristics, three or four are discernible in other transformation processes as well. But the presence of all six characteristics together is unique in world history.

Allow me to present this conclusion in advance for now. I will support it below by providing historical comparisons.

\subsection{Historical comparisons}

I will compare five kinds of typical "great transformations" with what has happened in Central Eastern Europe. It is obvious that in so doing we have not even begun to exhaust all comparative possibilities; a number of interesting and important cases have been left out. (For example, the changes taking place in Russia in the last fifteen years, the transformation of the Southern European dictatorships into democracies, or a brand new example: the changes taking place in Iraq since the fall of the regime of Saddam Hussein.) Regardless, the five transformation cases to be scrutinized present us with substantial lessons to be learned. It is not easy to follow the rhythm of these comparisons. To facilitate an understanding of this, Table 5 presents a comparative overview of the logical structure of the comparisons.

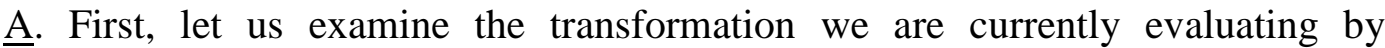
comparing it with the preceding movement which moved in the opposite direction: the destruction of the capitalist system and the creation of a socialist 
system. For brevity's sake I will restrict myself exclusively to Soviet history. There is similarity in characteristic No. 3: there too parallel changes transformed all spheres of society. The similarity is staggering in characteristic No. 6, the speed at which the changes took place. The Communist party grabbed power in 1917. The "great transformation" was completed by the end of 1932, with the collectivization of agriculture when private ownership of the means of production was basically eliminated. Only fifteen years were required to put everything in place for the creation of what we call "classical socialism". 12

The striking difference lies in characteristics No.1, No. 2 and No. 4. At the end of World War I, Russia was about to embark on the road toward establishing a Western type parliamentary democracy. A bloody revolution overthrew the earlier political authority, the tsar and his family were executed and the elite of the former regime were either killed or exiled into forced labor camps. Violence and terror imposed a new political and social order on society. This is a 180-degree opposite of the 19891990 velvet revolution and the non-violent nature of our current transformation.

In the remainder of my discussion, I will focus only on transformations which share characteristic No. 1 with those taking place in Central Eastern Europe, in other words where the changes in the economy point to the main direction (or at least are not turning away from the main direction) of the changes in the economic sphere.

B. Characteristic No. 4, the non-violent nature of the transformation cannot be considered to be self-evident. It is worthwhile to illustrate this with two historical examples.

After World War I, the Communists under the leadership of Béla Kun seized power in Hungary and proclaimed a Hungarian Soviet Republic. A few months later, under the leadership of Admiral Miklós Horthy, who became later Governor (i.e. head of state), the Communist rule was defeated and the former capitalist order was restored. The Red Terror was replaced by the White Terror during the initial months. Lynching, hangings and prison sentences were part and parcel of the transition and it took a few years until some sort of political consolidation was reached.

The second example is that of Chile. Here Allende and his government embarked on a path which presumably could have led to the formation of a socialist system. But before it developed fully, it was destroyed by a coup headed by General Pinochet in 1973. A vindictive campaign, extra-judicial reprisals, political murders and torture were the trademarks of the attempted restoration of the pre-Allende economic system. Only after much suffering and after many years could democratic institutions develop in that country.

Let us compare these two historical episodes with what has just taken place in Central Eastern Europe. In the eight countries that are the subject of the paper, the politicians of the former regime were neither executed nor imprisoned and there was no campaign of revenge conducted against them. In a number of countries, in preparation for a new constitution, civilized discussions were held between the leaders of the former ruling party and the new opposition leaders, who were readying themselves to take on political power. The power shift took place without bloodshed and without chaos at the highest levels of power.

As in our other cases, my aim so far has been simply to present the facts: assessment of their value will be offered in later sections.

$\underline{\mathrm{C}}$. The elimination of the socialist system continues to proceed in areas to the south and east of the eight countries under scrutiny. It would well fit into the logic of my analysis to take all the transformation processes one by one and make comparisons. Due to time constraints, however, I will compare the changes that have 
taken place in the Central Eastern European region with those of only one country, China. Of course, only the future will show how far the trend of the capitalist economic development in China will reach, and how consistent will it be.

In the case of characteristic No. 1 - and this is of fundamental importance - the Chinese and Central Eastern European transformations are identical: both point in the main historical direction, toward the capitalist economic system.

The most important difference, however, can be found in the case of characteristic No. 2. Regarding the political structure, the development of the Central Eastern European countries also points in the main direction of Western civilization: it has moved away from the previous system, towards democracy and respect for human rights. In contrast, in China, the monopoly power of the Communist Party has remained intact, resulting in repression and the curtailment of human rights. While substantial changes continue to take place in virtually every sphere of society, one cannot even begin to talk about the parallelism mentioned under characteristic No. 3 .

There is also a striking contrast to China's path regarding characteristic No. 4, the issue of non-violence. One cannot talk of a velvet revolution. Upon the death of the former tyrant Mao Zedong, the leadership struck those in his immediate environment with an iron fist. When the demands of the students of Beijing went too far in relation to the pace dictated by the rulers of the country, their protests were put down by military force. Those professing views displeasing to the party are put in jail.

In terms of characteristic No. 5, there is no substantial difference between the cases: as in the CEE, China's changes are not forced by the imposition of outside military intervention. Whatever change does take place has been carried out by the imposition of internal force.

The difference is very substantial in terms of characteristic No. 6: the pace of institutional changes in China has been much slower than in CEE.

D. Finally we consider the transformation of West-Germany during the period following World War II. We begin with characteristics No. 1 and No. 2. During the rule of the Nazis, the capitalist economic system basically continued to operate, but the political structure fatally deviated from the main direction. With regard to characteristic No. 3, there was no need for a complete transformation, only for a partial one. The most important differences can be found in characteristics No.4. and No.5. This obviously could not be a violence-free transformation. First, the power of the Nazis had to be destroyed in a war that required serious sacrifices, followed by punishment on the perpetrators of war crimes and crimes against humanity. The Allied Powers kept the country under occupation for a long period of time. The creation of basic democratic institutions was imposed from the outside through provision of the peace treaty enforced by the military presence of Allied troops. This became the starting point of the reforms brought about by internal forces. With regard to characteristic No. 6, the speed. measured on a historical scale, the democratization was very swift.

E. Having reached the end of these comparisons, it is time to return to the topic with which we began: the centuries-long process which led to the original formation of the capitalist economic system and democracy. In fact, several characteristics of these major transformations correspond to certain characteristics of the current (in comparison "small") transformation taking place in the Central Eastern European region. By definition, characteristics No. 1 and No. 2 are the same, since the characterization of "main direction" has been distilled from the major historical transformations. As for characteristic No. 3, if we look at the totality of the changes, it is clear that the economic and political transformation affected all spheres of social 
activity. However, if we consider these developments not in terms of centuries but instead in a much shorter time-frame, we cannot talk about the close parallelism which was observable in the Central Eastern European region during the past ten to fifteen years. In a sequence varying by country and with different time lags, events accelerated either in the political sphere, or in the religious-intellectual-ideological world, or in the economy. Considering characteristics No. 4 and No. 5 there are differences by country and period regarding how peaceful or devoid of violence the changes were, and when the changes were accelerated by bloody uprising, revolution, war and the conquest of foreign countries. Some historical schools maintain that the Modern Age began with the discovery (meaning: conquest) of America, while others date it to the outbreak of the French Revolution of 1789, which grew into a reign of terror.

The biggest divergence can be discerned, of course in characteristic No 6 , the speed of the change. It took capitalism centuries to become the prevalent economic system of an entire country. A centuries-long process preceded the realization of parliamentary democracy. By contrast, all of these have been completed with incredible speed in the Central Eastern European region now.

From the perspective of large-scale history, the transformation of the Central Eastern European region was indeed extremely swift. But it is important to recall that there were politicians and economic experts who urged even faster changes. The countries were encouraged to compete with each other. As in a running race, odds were weighed: where will privatization come to an end first? Would the Czechs, the Hungarians, or the Polish be crossing the finish line at the end of the sixth or the ninth year? If we analyze these events from a historical perspective, we can sense the bizarre nature of such a contest.

A part of the populace also viewed the race with suspicion. In the framework of an international research project intended to measure the individual's ordering of values citizens of a number of Central Eastern European countries were asked which they would prefer: the radical reorganization of society through a major revolutionary action, or a gradual improvement of society through reforms. Seventy-five percent of Czechs, eighty-two percent of Slovenes and sixty-seven percent of Lithuanians chose the latter (see Halman, 2001, p. 170.)

\subsection{Accelerating factors in the transformation process}

The comparative analysis of all six characteristics would deserve a separate study. Here, I discuss only one - the sixth. Having observed the gradual transformation of the past ten to fifteen years to be exceptionally speedy, we may pose the question: what made this great speed possible?

1. On our first attempt we would likely offer a simple answer: it is easier to do something for the second time than to create it in the first place. We could quote from the well known experiences of economic growth. The rebuilding of ruined economies has always been a faster process than the construction of original ones.

The "restoration" argument however, only holds partially.

Let us start with knowledge and experience. Even those individuals who in their youth had gained some experience in the political or economic sphere before the Communists came to power were close to retirement age when the transformation began: most who had been active in the pre-socialist era had already passed away or retired. This type of knowledge is not genetically transmitted, and there were not many families where the accumulated economic, business or political knowledge 
of the pre-socialist period would have been transmitted by the parents to their offspring. In the heads and thinking of individuals there was no such thing as a "restoration" of old knowledge, rather it was the gaining of new knowledge.

However, we can find many counterexamples. There were families during the socialist era, which preserved the old values and passed them onto the younger generations. It is not unheard of that grandchildren in one way or another carry on the trade of their grandparents. The socialist system destroyed the political, economic and social institutions which had operated in the previous era. They were not instantaneously resurrected. Nevertheless, counterexamples could be exhibited here also.

All together, it could be stated that: although the transformation has been accelerated by the fact that at many points it had been possible to return to earlier developed traditions, behaviors and institutions in order to utilize them as starting points - yet this reverting was not the strongest factor among the accelerating forces at all.

2. A significant proportion of individuals tend to instinctively take care of their own affairs, and have a spirit of entrepreneurship. The multitude of restrictions imposed by medieval society curtailed the amplification of this spontaneous endeavor and these barriers were only gradually and slowly eliminated. The loosening and the breaking down of the restrictions of the feudal order, and the expansion of private property and market coordination are intertwined processes. The socialist economic system incorporated even more crippling constraints into the system than those of its predecessors: it virtually hamstrung the proclivity for initiative and entrepreneurship. During the post-socialist transformation period the bureaucratic prohibitions set up by the socialist centralized economic administration were not slowly and gradually dismantled but broken down at breakneck speed. For this reason, the spirit of spontaneous entrepreneurship, this unique driving force of capitalism, literally burst into the economic scene.

3. There was no strong resistance to the transformation. When capitalism and parliamentary democracy developed slowly and gradually for the first time, there were various strata, groups, and classes of society who fought against it. The new order won in the struggle against the beneficiaries of the ancien régime. After the victories of the new order, the adherents of the old order engaged in a political, ideological and, in some cases, armed resistance against it.

This time it was different. Six years after Gorbachev started his reforms, by the time of the collapse of the Berlin Wall, the leaders of the communist order in CentralEastern Europe had already put down their arms. There were no movements inciting against the new order, its opponents did not resort to arms, there were no guerilla fighters or terrorists. The majority of the members of the former 'old guard' had become disillusioned with their former ideals. The more resourceful ones changed sides, they tried to become businessmen - many successfully - even active players in the democratic political arena. Others wearily retired.

4. The most significant explanation for the rapidity of the transformation can be found in the effects of the external world surrounding the Central Eastern European countries. The expression "external world" is used in its widest possible sense to refer to various outside influences and circumstances.

One of the effects was the adoption of foreign examples. From the operational forms of corporate management and banking system to political institutions, from media programs to advertising, from the organization of educational activities to the 
financing of the arts and sciences, there was hardly an area of social activity where foreign examples have not been followed.

There were numerous channels through which these examples found their way to the Central Eastern European population. People became acquainted with them during their trips abroad, some prior to 1990, many more after the changes took place. They read about them, or watched them in the movies. Teaching about the foreign experience took place in schools, at universities, and at special seminars. Foreign consultants recommended their adoption.

I am not claiming that the adaptation of foreign models is an easy matter. It is not enough just to observe how the British Parliament or a bank in Zurich works and then expect that everything will happen in the same way at the Hungarian or at the Estonian Parliaments, in the Czech or in the Polish banks. It is easy enough to recognize the model, but it is a much more difficult task to learn how to use it, and to adapt it to the local conditions. If learning were not a difficult and contradictory process, then the realization of the bulk of the transformation would not had taken fifteen years to complete, and we would not need further cumbersome work to apply the model more effectively.

Foreign investors also exerted an extraordinary influence. Not only did they bring in capital, but — in addition to technical know-how - they brought knowledge about how to manage a company, and about what kind of legal system and behavioral norms are requirements for the operation of a capitalist economy.

The eight countries under consideration joined important international organizations - under Western leadership - such as NATO, OECD, and the WTO, and their relationships became more active with the World Bank and the IMF. The succession of various memberships culminated in their accession to the European Union. What in the language of Brussels is dubbed as the process of "harmonization" took place not only in the realm of legislation. In every respect, Central Eastern Europe tried to assimilate Western examples. This accommodation was compelled and primarily driven by internal forces. However, it is no use denying that a certain level of external political pressure was also discernible. Characteristic No. 5 is relevant in that there was no foreign military occupation. Not a single foreign country, not even the great powers, "pushed" the small countries of Central Eastern Europe around. However, "conditionality" did exist. The practice started with the Washington-based financial organizations and was gradually taken up by the European Union according to which the availability of funds for loans and grants, the expansion of existing relationships and the guaranteeing of various additional rights were increasingly tied to the satisfaction of certain preconditions. It is true, however, that these preconditions were generally formulated in such a way as to serve the long-term interests of the individual countries concerned. Still, many changes were forced upon them through external pressures or, at the very least, these pressures contributed to the speedier implementation of changes.

The geographical proximity of the Western world must have contributed to the intensity of the external pressures. The quickest ones of the recent great transitions took place precisely in those counties that were located directly on the border of the developed European countries.

5. The availability of modern technology was an important accelerating factor in the process. In this context, we are not referring to any special situation enjoyed by the Central Eastern European region. The pace of the European transformation was faster in part because nowadays everything changes at a faster pace. Consider, for example, the speed of transportation and communication at the end of 
the Middle Ages and at the beginning of the Modern Age, and compare them with the possibilities available to us today. Computers, the internet, e-mail and the mobile phone - to mention only four - exponentially accelerate the arrival of outside information for those desiring to emulate outside examples. This new technology contributed to the accelerated pace of the publication and dissemination of new regulations and norms.

Even though there was an incredible lag in the dispersion of "high-tech" in the region before the transition, its speed of development was significantly accelerated. It is true, that the spread of computers and the use of the internet is still relatively low. ${ }^{13}$ One thing that appears to be certain, however, is that information reaches decision makers and public opinion makers quite swiftly and the media is able to disseminate it rapidly to millions of people.

\subsection{The first assessment: an unparalleled success story}

I am convinced that what took place in Central Eastern Europe during the past decade and a half, is an unparalleled success story in history. I believe this, in spite of the fact that I am fully aware of the grief and disappointment it was associated with - an issue I am going to address during the second half of the paper. So, to be a bit more precise, here is my assessment: in spite of serious problems and anomalies assessing the situation from the perspective of great historical changes - what took place in this part of the world, is a success story.

My conviction is based on a particular ordering of values. Others, basing their judgments on a different ordering of values may disagree.

On a scale of values, I accord pride of place to democracy and human rights. Perhaps this is because - together with many of my contemporaries in Central Eastern Europe - I lived through various forms of tyranny in which we experienced total deprivation of civil rights or a humiliating curtailment of human rights and in which we were subjected to brutal discrimination applied along various criteria. This is why I feel a strong aversion to arguments comparing China's performance with that of the Central Eastern European region, which put biased and one-sided emphasis on its much higher economic growth. It is true that the growth-rate in the Central Eastern European region is a great deal lower than that of China, though it is still respectable, and, as I pointed out above, the pace is already faster than it was during the last decade of the previous regime. I am ready to resign myself to a lower rate of growth than the leaps and bounds produced by the Chinese so long as it is coupled with a respect for democracy and human rights! I acknowledge that there are those who do not see the world in this way and who believe it may be worthwhile to forego, or postpone, democracy for an indefinite period as in order to achieve rapid economic growth.

At many times, the political institutions of democracy uncomfortably impede the concentration of the state's capacities on the promotion of growth, as well as on the forceful completion of reforms associated with greater convulsions. In my eyes, these drawbacks are far outweighed by the advantages of greater freedom rights provided by democracy. For Central-Eastern Europeans, the fact that the integration with the European Union acts as a stabilizing force both in the political sphere and in the economy, facilitates the creation of democracy.

I consider the transformation of the Central Eastern European region a success story because it established a capitalist economic system within a historically brief time frame, thereby placing our nations again on the course of development leading toward the main direction of history. It is not that I "love" capitalism. It is not a very 
likeable system. But I hold those of its characteristics dear which are indispensable to the realization of the values I profess. In the long run, the economic advantages of capitalism will become manifest in the Central Eastern European region, too: a sustainable higher growth rate of production, productivity and consumption than the one experienced under the socialist system, technical innovation, entrepreneurial spirit, and together with the above, an increasing level of prosperity for society as a whole. I also consider the values of economic growth and the increase in the standard of living it brings to be primary values. (Though, not with the finality and onesidedness of those who would be willing to give up democracy for it.) Beyond the argument for the increase of material goods, there is another that has been mentioned earlier: the very existence of a capitalist system is an indispensable precondition for a functioning democracy. These are those benefits that according to my ordering of values overshadow the disadvantages of capitalism. I acknowledge that there are others who subscribe to a different system for weighing the advantages and disadvantages between them.

And finally, I consider the transformation of the Central Eastern European region a success story because it took place in a peaceful manner, devoid of violence. My own life experience must have provided the formative impression for my views regarding this. I survived a World War, bloody persecutions, hard and soft dictatorships, vindictive campaigns, the execution and incarceration of friends. It was enough! For me, the fact that this time there was no bloodshed, that no one was killed or imprisoned, was an extraordinarily beneficial development. I admit that there are those who view these changes differently. They believe that changes could have happened earlier had the former regime been overthrown sooner, even by resorting to the force of arms. There are those who condemn the lack of punishment for the guilty and find the dispensing of justice wanting.

The fact that external influences played a major role among the driving forces behind these changes does not change my favorable opinion. Foreign influences, such as knowledge, experience, culture and capital flowed into the Central Eastern European countries, enabling them to be better integrated into the European Union and into a globalized world. I am aware that some people feel offended by this, as they are concerned about the preservation of national traditions. They may also be disturbed by the fact that all of this will undoubtedly result in placing limits on the political sovereignty of the individual states. I admit that here we are facing a difficult trade-off.

I have tried to openly and without circumlocution disclose the ordering of values that underlie my own judgement. I do not do this for the sake of arguing for it. There is no place here for rational argumentation, something that we economists always attempt to engage in. There are meta-rational ideas, beliefs and desires concealed behind these valuations - and in this regard, it is unavoidable that there will be divergences of opinion between individuals professing different worldviews. Even if - from the perspective of the great events of world history - we were to agree on what actually took place in the Central Eastern European region, we cannot count on arriving at a consensus in assessing the results.

\section{From the perspective of everyday life}

\subsection{Problems and worries}


Emotions of success and failure intermingle in everyone's life who either participated or was an empathetic observer of the transformation taking place in the Central Eastern European region. Far be it from me to engage in a cheap "success propaganda" campaign. We are not facing imaginary difficulties, nor are these problems encountered by a small portion of the populace; we are up against some very real and serious negative phenomena.

In the beginning of the new era, the real income of the majority of citizens living in the Central Eastern European region was significantly below the average for member countries of the European Union, and a considerable proportion were at the poverty level. Since that time, - regardless of how much the world changed around us, - the real income of a significant proportion of the population has remained unchanged, and many among the impoverished have become mired at the low level of their earlier living standard. And there are a non-negligible number of people whose standard of living has discernibly deteriorated.. We cannot be certain that in every case, the degradation was attributable to the change in the political system, but it certainly took place during the period since 1990 . These are those individuals who consider themselves the unequivocal victims of this era.

A dramatic restructuring has taken place in the area of the distribution of income and consumption. Though critics of the socialist system rightfully complained that a system of material privileges did indeed exist, the distribution of income and consumption generally lay within a rather narrow range. The ten to fifteen years since then has been enough to affect a marked increase in the existing levels of inequality, as shown in Tables 6 and 7. ${ }^{14}$ On one side, a heretofore unknown level of conspicuous wealth has become readily apparent, while on the other, the poverty that was less obviously manifest before, has became more deeply entrenched and much more visible. This is appalling to the sense of social justice of many individuals who were otherwise not victims of the restructuring.

The serious problems enumerated above are connected to issues of employment. Open unemployment was unknown in the socialist economy; the employment rate was very high, every worker could feel secure at his or her workplace. Indeed, an inverse disequilibrium prevailed. The socialist economy created chronic shortages, including a chronic labor shortage - at least, in the more developed and industrialized Central Eastern European countries. Whatever effect that had on efficiency, the workers enjoyed job security. This has come to an end. The employment rate has significantly declined and open unemployment has appeared. Its rate differs from country to country and there are some Central Eastern European countries where the percentages are lower than the overall European average and others where they are higher, as shown in Table 8. Unemployment came crashing down as a virtual trauma on the society, as seen in Table 9.

Job security disappeared. This happened at a time when life itself became more insecure on countless fronts. In socialist societies, those who avoided risky political activity were surrounded by relatively solid and predictable conditions of livelihood. Now, all of a sudden, everything is in motion and nothing is known in advance. Formerly, a company existed forever and ever; nowadays, they are formed and go broke from one day to the next. Previously, consumer prices were fixed for long periods of time, now they are in a constant state of flux. The average citizen cannot make sense of interest rates, or even rates of exchange. Though it used to be incredibly difficult to get an apartment, once you got one, whether as a tenant or the occupant of a sublet, it was virtually impossible to be evicted. Nowadays, you can be evicted for simply not paying the rent. As the police state was being dismantled, 
public security was deteriorating. (See Table 10.) Everything that had been stiffened to the point of rigidity by overbearing authorities and bureaucracy became malleable, risky and insecure through the influence of market forces, competition, and civil rights guaranteeing more freedom of movement.

Corruption existed during the old regime too, mostly in areas of mutual favors bestowed through political or personal contacts. Though there were even incidents of bribing, these were uncommon and generally took place at the lower levels of the "shortage" economy, to 'grease the wheels'. The majority of corrupt activities remained unseen and behind the scenes. Nowadays corruption is ubiquitous in the myriad of transactions in the political, economic and cultural sphere, in private transactions large and small, and at the highest and lowest levels of the governmental and social hierarchy. Many corruption cases become public knowledge. Everyone is angry, and - often unwillingly - many people get dirty. It is almost impossible to avoid becoming involved in some transaction where one or another of the parties engages in certain shady transactions, and where either the client, the citizen, the seller or the buyer, would not attempt to bribe, or be involved in a phony tax evasion scheme of some sort.

People are also upset about the disorders present in the political arena. Many view the multi-party system as not having created the preconditions for a sober political competition, but instead of having resulted in an unbridled struggle for power, lies, empty promises and the continual ranting and raving of the opposition against whoever happens to be in power. A significant proportion of the population does not place sufficient trust in their Parliament. In this respect, the difference between the 15 old and the 8 new EU members is enormous as seen in Table 11. Politicians are suspected of having been involved in corruption, sometimes because they violated the law, or at the least the unwritten law of ethics, and sometimes because they are slandered by political rivals.

I have mentioned some of the most serious issues. Though I could continue, I think this much should be sufficient to demonstrate that we are not talking about trifling inconveniences, but about genuinely overwhelming and serious problems.

\subsection{Social disposition}

There have been numerous surveys assessing the prevailing mood and social disposition of the citizenry of the Central Eastern European countries. They point to the fact that these opinions are divided. Many more respondents in the older EU member states answered 'yes' to the (apparently) simple question "Are you satisfied with your life?" than in the eight new member states under consideration, as shown in Table 12. The ratio of negative answers differs from country to country, as seen in Table 13. As an approximate average it appears that every third person in the region is either somewhat or very dissatisfied with his life. ${ }^{15}$

\subsection{Cognitive problems}

The intensity of people's reaction to troubles, or its degree of bitterness is not merely a function of the real difficulties associated with the problem itself. When one experiences hardship, or observes the troubled with empathy, a great deal depends on how one perceives the problem at hand, and how one deals with it. Let us attempt to survey some of the most important cognitive problems from the standpoint of our topic. 
1. Prior to something happening we entertain certain hopes and expectations. After something happens we are often disappointed. ${ }^{16}$ As the disillusionment over socialism began to take hold, expectations became more pronounced. The hope emerged that a change of the system would resolve all problems, quickly, for everyone.

Rightful hopes were intermingled with misconceptions and false illusions. Expressions like the "West", the "market", "competition", and "democracy", resulted in mythical images which promised light without shade. Sobering words were few and far between, especially from the mouths of credible individuals. (When adherents of the old regime railed against capitalism, fewer and fewer people listened to them.)

The first great hopes got a cold shower with the serious transformational recession of the nineties. The people had barely time to recover before new and unrealistic expectations were formed again, this time in regard to membership in the European Union. These were kindled by various phrases referring to the "convergence", and promises of multifaceted support to be supplied by the European Union. Many looked forward to the manifest and imminent benefits of accession with naïve impatience.

The problems are great. But they are magnified to even larger sizes as the result of disillusionment.

2. A well-known phenomenon in social psychology is that how one feels about something is dependent not only on the real circumstances, but also on whom the individual compares himself to. During the period of loosening of the socialist system, people living in the Western periphery of the Soviet empire comforted themselves by noting that they still were better off than those living in the Soviet Union. Especially in a place like Hungary, my home country, where experiments with market-economic reforms had been going on for some time, this self-encouragement even sounded credible. But as the borders of these countries opened, and especially now that they became member states of the European Union, the "reference points" have generally shifted. Everyone has started to compare his own circumstances with that of Germany, France or Scandinavia. Of course, the higher one's standards of comparison, the more one will become dissatisfied with the place where one happens to live. The impatience is understandable: now that we are members of the European Union, when will we catch up with our fellow member states? But it also leads to hopeless desires. Those clinging to the Western frame of reference are likely to remain permanently bitter, impatient and disillusioned.

3. People very easily forget; both collective and individual memories are highly unreliable. Decades ago, we were flooded with complaints from individuals because certain consumer items were unavailable: one had to wait many years for a car or an apartment or a telephone line. Nowadays it seems that I, once the author of a book entitled Economics of Shortage (1980), will be left as the single individual in Eastern Europe, who still remembers the shortage economy and feels genuine joy that it is over. Chronic shortages have been replaced by abundant supplies. Nowadays, people grumble that we are awash in an incredible number of products, that prices are prohibitively expensive and that people are tormented by the "consumer society".

As a result of these poorly working memories, fundamentally important achievements, material and non-material benefits are being disparaged (such as freedom of speech, association and movement, the free competition of ideas, the right to protest and so on), even though they are clearly discernible in people's everyday lives. Instead, current problems are accorded a greater relative weight. 
In a 2004 survey individuals were asked to indicate on a scale ranging from -100 to 100 their evaluation of the current government as compared to that prior to the change in the political system, as seen in Table 14 and in its interpretation by Rose (2005). Although the incumbent governments received higher scores, it is remarkable that the ratings accorded to the previous system were not far behind. Grotesquely, all this leads to feelings of nostalgia. Many of those who muttered and hoped for changes during the Communist era find themselves thinking that the old regime was not that bad after all.

4. Finally, I would like to mention the flaws of causal analysis.

\subsection{Causal analysis}

There are many causes of the problems and difficulties suffered by the people of Central Eastern Europe. I will only emphasize a few of them.

The region's level of development lags behind the West. This is not a new phenomenon; things have been this way for centuries. As one can see in Table 15, during the socialist period this relative gap expanded even further. There is a good chance that the relative backlog will gradually diminish, but it is highly unlikely that anything could occur in the social-economic-political arena that would fill the gap (which is more like an abyss!) in the immediate future, as shown in Table 16. Many of the negative phenomena, as well as the poverty, the lag in technological development, and the scarcity of available resources for health-care, education and scientific research, can be explained primarily (but not exclusively) by the fact that the region is at the medium level of development, well behind the front runners.

Part of the trouble is also due to the fact that we are in transition. The structure of production had to be reorganized, since while old production lines ceased to exist, new ones did not take their place immediately. A new vacuum, new loopholes and an absence of regulation came into being in the midst of institutional transformation. While in many places the old guard was removed, the new management was still inexperienced. The fact that these difficulties are of a transitional nature is not sufficient to reassure everyone, for it is difficult to wait for them to be over with.

Other problems emanate from the very nature of the system. Like every system, capitalism has certain inborn system-specific negative characteristics As long as capitalism is what it is, there will be unemployment, there will be income-inequality, there will be economic winners and losers, and there will be excessive advertisements and so on. Wise, forward-looking and consistent governmental policies can mitigate some of the genetic faults but they cannot completely eliminate them. Serious and level-headed believers in the capitalist system accept these problems because, despite its deficiencies, they find the overall package more palatable than the socialist system.

The same thing can be said about democracy. The great multitudes of Central Eastern Europeans who are becoming disenchanted with democracy are like disillusioned lovers. They are irritated by the often barren verbal tirades taking place in parliament, by the mutual accusations leveled by various political parties at one another, by lying promises, and by seeing scandalous affairs swept under the rug. Yet these are not anomalies associated with young democracies! Similar phenomena can be frequently observed in great democracies with a long history; they are not restricted to relative newcomers. The importance of the truth reflected in Churchill's words will not be diminished, though they have been quoted millions of times. Even given all its faults, democracy is still a better system than any form of tyranny, regardless of how wise, enlightened or clean-handed a dictator might be. Unfortunately, in the Central Eastern European countries a 
non-negligible proportion of the population does not think this way. Table 17 draws attention to disturbing phenomena.

Wrong decisions made by politicians - governments, the ruling party or the opposition, or the leadership of various advocacy groups - may create troubles, or exacerbate pre-existing difficulties brought on by extraneous circumstances. Consider the following example. It can be stated with certainty that capitalism gives birth to disparity. But tax policies favoring the rich while afflicting the impoverished, or poorly distributed state subsidies, can make matters even worse.

I have identified five different causes for the current problems, (medium level of development, problems brought on by the transition, the system-specific problems of capitalism and those of democracy, and wrong decisions made by politicians); and of course there are others. One reason for the existence of a feeling of general malaise in society is in the confusion of these various causes in people's minds. In cases of multi-causal phenomena, the objective and clear identification and separation of various causes poses a difficult task, even for professional analysts. Small wonder that errors are creeping in the explanation of causes in the mind of people not specialized in the subject.

\subsection{Once more about value judgments}

I have tried to refrain from false generalization. So let me reiterate, as I emphasized earlier, that public opinion is divided: attitudes range from satisfaction with minor reservations, to grumbling and complaining, all the way to angry dissatisfaction. Allow me to make a few comments concerning the mood of those whose judgment tends to lean more towards the negative.

Among those who offer these negative judgments, there is an unfortunate mixture of half-true and half-erroneous establishment of the facts, a combination of halfsubstantiated and half-mistaken causal analysis, and an ordering of values that places the values of everyday life at the forefront. Those who judge from this perspective are not thinking in centuries-long historical perspective. They do not care what results the capitalist economic system and the democratic political order will produce in the distant future. They are experiencing these problems today, they are suffering from them now, or they are hurt by seeing others who are suffering now-and for this reason, their experience of the change that occurred in the system is as a failure, rather than a success.

No one has the right to disregard the negative judgments of disappointed individuals. No one has the right to accuse them of shortsightedness, or of turning a blind eye towards the comprehension of great historical interrelationships. Every person has only one life. Someone who is, say, fifty or sixty and poor, perhaps also unemployed will not be compensated by the promise that later generations being better off, for he will not have the chance to enjoy it. It is even difficult to bid the younger generation to have patience, since not a lost moment today can be truly compensated later with a better one.

For this reason, should I retract the statement made in the first half of the paper, when I said that the great transformation of the Central Eastern European region could be fundamentally characterized as an unparalleled success? No, I do not want to retract this. I do not believe it to be possible, or for that matter, permissible, to compile some kind of balance sheet for the sake of a summary and comprehensive value judgment. On such a view, there are the successes (with a positive sign), and there are the failures (with a negative sign), and if the balance is positive, then the 
ultimate outcome should be declared a success; if negative, then it must be looked upon as a failure. I cannot accept this simple additive "balance-sheet" approach.

I keep two accounts and not one, and do not merge them. On one account, I gladly acknowledge a great success at the level of world-history: a system was created superior to the former one, without bloodshed, with incredible speed. On the other account, I have the list of good and bad experience in everyday life; much joy and much pain. I consider it both sensible and defensible to say that what has happened in this region can be simultaneously considered a success in terms of its global historical significance, and a failure in many important aspects because it caused pain, bitterness and disappointment for so many people.

\section{On the tasks of the economic profession}

I have no intention of blaming the man in the street for not having flawlessly processed his experiences and perhaps for having come to mistaken conclusions in his mind regarding these problems. But I would not accord the same dispensation to ourselves, those doing research in the field of economics. I am not addressing this only to those who happen to live in Central Eastern Europe, but to all who are concerned with this region or similar issues, wherever they may live.

Perhaps we may have gone too far in our acceptance of the famous comment by Keynes, according to which, we are all going to be dead in the long run. The type of real long-term analysis I attempted to deal with during the first half of the paper is quite rare. Nowadays in many Ph.D. programs economists are not even required to study history. One of the reasons for the overly negative judgment prevailing in Central Eastern European public opinion circles regarding the current great transformation is that scholars of the social sciences have neglected to analyze and evaluate the results within the requisite historical framework.

The various social science disciplines are separated not only from historical science, but also from each other. In preparing for this paper I encountered the unfortunate phenomenon that in the political-science literature that deals with the transformation from dictatorship to democracy, one finds almost no reference to studies of economists, while economists virtually ignore the works of political science. Without interdisciplinary approach, it is impossible to understand and to evaluate the great transformations.

Mainstream economics relinquishes profound criticism of the capitalist economy to those professing radical views. Even when it accepts the fact that there may be problems, it lulls itself into believing that these problems can be reassuringly resolved by applying appropriate measures. It denies that the system may have inborn, insurmountable genetic defects.

In our profession, the careful and conscientious separation between the establishment of facts and their valuation is rather rare. It is not customary to frankly point out the ordering of values hidden behind the declaration of an economist. We consider it as self evident that all share the implicit values accepted axiomatically by our trade: efficiency, productivity, competitiveness, growth, perhaps the principle of fair distribution of income; however, beyond these, very few pay attention to any other values.

There are academic economists who are happy to address a wider audience or the reading public. Even those who do not endeavor to do so, exert their indirect influence. Leading politicians, statesmen, businessmen, newspaper reporters and analysts who formulate public opinion pay heed to them. Not only can we make the 
great transformations more successful by making correct economic policy recommendations' we can also contribute to the more informed and well-balanced processing of the experiences and to helping people to find the right valuation of changes.

The great transformation in Central Eastern Europe is over. I have heard the ironic comment from my colleagues more than once: "With this, so much for your weird science of 'transitology'." I do not believe so. How is the transformation of China and Vietnam going to continue? What is going to happen in Cuba? How will the great transformation proceed in an Iraq under foreign military occupation? How will Iran be transformed? What transformation will take place in the Muslim countries?

Every transformation is different. Nevertheless, there are common elements. And we can only truly understand the unique properties of each country if we compare it with others. Not only is 'transitology' not over; its work has not even begun with the desired thorough approach. I hope that the paper would spur a conscientious study of the accumulated body of knowledge on this subject.

\section{Notes}

1 There have been several documents commissioned by the European Union to evaluate the status of the candidate countries. Thus, for example, just before the accession, a publication entitled the Comprehensive Monitoring Report (European Commission, 2004) was compiled. A good insight into this topic is provided by the annual Transition Reports of the European Bank for Reconstruction and Development (see, for example, EBRD, 2002).

I am mentioning some of the recent publications of academic authors that are often cited by the experts: Campos and Coricelli (2002), Csaba (2005), Kolodko (2000), Kornai (2000), Roland (2000), Stiglitz (1999) and Svejnar (2002).

2 It is not within the scope of my presentation to offer a definition of the term "Western civilization," or to enumerate its characteristics or delineate its borders. I use the term merely suggestively. Since it does not belong to the subject of my analysis, I leave the question open, whether outside of the region that is often referred to as the "Western civilization", the trends outlined in this study has already appeared or will appear in the future.

The historical spread of the capitalist economy is primarily emphasized by the various Marxist and neo-Marxist schools (see, for example, Brenner, 1976, and the literature of the so called "Brenner-Debate"). Other streams of historical science, such as representatives of the French Annales school, recognize and also recognize this tendency as important.. I refer primarily to the works of Fernand Braudel (1972-1973, 1992), as well as to Immanuel Wallerstein's (1974, 1979) writings in which he combined Braudel's ideas with the findings of the neo-Marxist schools.

${ }^{3}$ In some of my other writings, for example in The Socialist System (1992) I have attempted to give a more concise definition. I content myself here with a looser description of "capitalism," one which is sufficient to encompass other characterizations and avert conceptual debate.] 
4 Consider the following representative publications which concern the issue of periodization - in particular, the topic of the beginning and end of the Middle Ages: Marc Bloch (1989), Jacques Le Goff (1982), Henri Pirenne (1937), and Peter Raeds (2001).

I am grateful to Gábor Klaniczay, who assisted me in gaining insight into the discourse of historians examining this very subject; his article (2001) provides an indepth overview of the literature written on the subject of transition from the Middle Ages to the Modern Age.

In an interview, Peter Burke (1990) the well-known British historian stated: "Nobody can agree as to when the early modern period begins..." Perhaps we as present day economists and other scholars of the social sciences are too close to the events and it is for this reason that we could so easily agree on one thing: the fall of the Berlin Wall is viewed as the start of a new period in the region. Or, perhaps there is a greater degree of homogeneity and synchronization present in the events than it there was during earlier periods of history.

${ }^{5}$ Luxemburg and West Germany were excluded from the table due to unavailability of data.

${ }^{6}$ I would like to accentuate a few from the rich literature: Haggard and Kaufman (2005), Huntington (1991), O'Donnel, Schmitter, and Whitehead (1988), and Przeworski (1991).

${ }^{7}$ See, for example Offe (1996) and McFaul (2002).

${ }^{8}$ Schumpeter (1942) introduced this criterion, which put the procedure of attaining and forfeiting power in the foreground, into the realm of political philosophy. Following Schumpeter's interpretation, in my study (1998) of post-socialist regime change I highlighted the replacement of a government based on a parliamentary election as a practically well applicable test. In her book, Susan Rose-Ackerman (2005) very aptly dubbed the procedural approach as the so-called "minimalist" interpretation of democracy. About the interpretation of democracy see also Dahl (1971), and additionally Schmitter and Karl (1991).

${ }^{9}$ About the connection between democracy and capitalism, several sharply conflicting views have developed over time. For me the most convincing argument is according to which capitalism is a necessary, but not sufficient condition of democracy. Among the classical figures of this topic, Hayek (1944) agreed with this statement while Schumpeter (1942) thought that democracy could evolve without capitalism. See also Rueschemeyer, Stephens and Stephens (1992), and Usher (1981) about this relationship.

${ }^{10}$ I want to reiterate that my ideas about the main directions are restricted to "Western civilization". I make no attempt to apply this concept mechanically to other civilizations. Such comparative analysis lies beyond the scope of this current study.

11 This is the title of Polányi's best known work The Great Transformation (1962).

${ }^{12}$ As far as characteristic No. 5 is concerned, in the Soviet Union the revolutionary transformation did not take place on the orders of foreign occupiers but was dictated by the domestic political power structure. There was a different situation in Eastern Europe, where the will of the Soviet political leadership proved to be the final 
authority. Nobody could refuse their orders due to the presence of Soviet military occupation forces.

${ }^{13} \mathrm{TV}$ and cell-phones are the exception, both of which are in wide use.

${ }^{14}$ Some Hungarian analyses show larger inequalities than the ones identified in Table 6. (see, for example, Tóth, 2004).

15 The data in Tables 12 and 13 are from different sources, based on different surveys. It is worth noting that despite the two kinds of approaches, the characteristic differences between the regions are quite close to each other.

${ }^{16}$ Albert O. Hirschman (1982) pointed out that disappointment was a part of the human condition. He refers to Kant, who stated: "Even if you were to grant man everything he wishes, all the same, at that very moment he will feel that that everything is not everything." (See Karamzin, 2003, pp. 40)

Especially the denizens of Western civilization are experiencing a state of ever present insatiability and disillusionment. In our case, this general feeling was further exacerbated by the frustration felt over the unrealized special expectations that followed the transition from socialism.

17 This list excludes references used exclusively as statistical sources for tables, unless the source is published article or book. 
Table 1

\section{Growth rates in socialism and capitalism}

\begin{tabular}{|c|c|c|c|c|c|c|c|}
\hline \multirow[b]{3}{*}{ Country } & \multicolumn{3}{|c|}{ GDP per capita } & \multicolumn{4}{|c|}{ Average growth rates of GDP per capita } \\
\hline & \multicolumn{2}{|c|}{ (1990 Int'l dollars) } & \multirow{2}{*}{$\frac{(1950=100)}{1990}$} & \multicolumn{4}{|c|}{ (percent) } \\
\hline & 1950 & 1989 & & $1950 s$ & $1960 s$ & $1970 s$ & $1980 s$ \\
\hline Czechoslovakia & 3501 & 8768 & 250 & 3.9 & 2.9 & 2.1 & 1.2 \\
\hline USSR & 2841 & 7098 & 250 & 3.4 & 3.6 & 2.2 & 0.9 \\
\hline Poland & 2447 & 5684 & 232 & 2.4 & 3.2 & 3.4 & -0.4 \\
\hline Hungary & 2480 & 6903 & 278 & 4.0 & 3.8 & 2.1 & 1.0 \\
\hline Socialist 4 & 2819 & 7013 & 239 & 3.3 & 3.5 & 2.3 & 0.8 \\
\hline Austria & 3706 & 16369 & 442 & 6.3 & 4.2 & 3.9 & 2.0 \\
\hline Belgium & 5462 & 16744 & 307 & 2.4 & 4.2 & 3.3 & 1.9 \\
\hline Denmark & 6943 & 18261 & 263 & 2.9 & 3.8 & 2.0 & 1.8 \\
\hline Finland & 4253 & 16946 & 398 & 3.3 & 4.4 & 3.3 & 3.2 \\
\hline France & 5271 & 17730 & 336 & 3.7 & 4.6 & 3.0 & 1.7 \\
\hline Greece & 1915 & 10086 & 527 & 5.0 & 6.6 & 4.4 & 1.3 \\
\hline Ireland & 3453 & 10880 & 315 & 1.7 & 4.2 & 3.2 & 2.7 \\
\hline Italy & 3502 & 15969 & 456 & 5.6 & 5.4 & 2.9 & 2.3 \\
\hline Netherlands & 5996 & 16695 & 278 & 2.8 & 4.0 & 2.5 & 1.3 \\
\hline Portugal & 2086 & 10372 & 497 & 3.1 & 6.0 & 4.5 & 3.0 \\
\hline Spain & 2189 & 11582 & 529 & 3.5 & 7.1 & 4.2 & 2.5 \\
\hline Sweden & 6739 & 17593 & 261 & 2.5 & 3.8 & 2.0 & 1.8 \\
\hline UK & 6939 & 16414 & 237 & 1.7 & 2.5 & 2.2 & 2.2 \\
\hline$E U 13$ & 4688 & 15519 & 337 & 3.2 & 4.3 & 2.9 & 2.1 \\
\hline
\end{tabular}

Notes: Data for Luxembourg are not available. Data for Germany were excluded, because they were available only for Germany in its 1991 (unified) borders. The 1949 figure was not available for Poland to calculate growth p.c. in 1950; the 1950s average growth rate is on for 1951-59 period.

Source: OECD database accompanying Maddison (2003). 
Table 2

Growth before and after 1989, and after transformational recession

\begin{tabular}{|c|c|c|c|c|c|c|}
\hline \multirow[b]{3}{*}{ Country } & \multicolumn{4}{|c|}{ GDP/NMP index } & \multicolumn{2}{|c|}{ Average annual growth rate } \\
\hline & \multicolumn{4}{|c|}{$(1989=100)$} & \multicolumn{2}{|c|}{ (percent) } \\
\hline & 1980 & 1990 & 1995 & 2003 & $1980-1989$ & $1995-2003$ \\
\hline Czech Republic & 85 & 99 & 94 & 106 & 1.8 & 1.5 \\
\hline Estonia & 75 & 92 & 66 & 101 & 3.2 & 5.5 \\
\hline Hungary & 86 & 97 & 86 & 116 & 1.7 & 3.8 \\
\hline Latvia & 69 & 103 & 51 & 79 & 4.2 & 5.6 \\
\hline Lithuania & 65 & 97 & 56 & 81 & 4.9 & 4.7 \\
\hline Poland & 91 & 88 & 99 & 135 & 1.1 & 4.0 \\
\hline Slovakia & 85 & 98 & 84 & 117 & 1.8 & 4.2 \\
\hline Slovenia & 99 & 92 & 89 & 120 & 0.1 & 3.8 \\
\hline CEE 8 & 86 & 94 & 91 & 121 & 1.7 & 3.6 \\
\hline EU 15 & .. & 103 & 111 & 132 & .. & 2.2 \\
\hline
\end{tabular}

Notes: Pre-1990 growth rates for CEE 8 are based on the Net Material Product (NMP) used by for the growth accounting by the socialist countries. The 1980 figure for the Czech and Slovak republics is for Czechoslovakia.

Sources: Based on UN Economic Commission for Europe (UN ECE) Economic Survey of Europe 2001, n.1, p. 254 and UN ECE Economic Survey of Europe 1999, n. 1, Table A.1.; updated from UN ECE Economic Survey of Europe 2005, n.1, p. 117. 
Table 3

Average growth rates for the years 1995-2003

\begin{tabular}{|c|c|c|c|}
\hline Country & $\begin{array}{c}\text { Average real } \\
\text { GDP per } \\
\text { capita } \\
\text { growth }\end{array}$ & $\begin{array}{c}\text { Average } \\
\text { labor } \\
\text { productivity } \\
\text { growth } \\
\text { (percent) }\end{array}$ & $\begin{array}{c}\text { Average } \\
\text { consumption } \\
\text { per capita } \\
\text { growth }\end{array}$ \\
\hline Czech Republic & 2.2 & 2.6 & 3.0 \\
\hline Estonia & 6.6 & 6.6 & 7.3 \\
\hline Hungary & 4.1 & 3.2 & 4.5 \\
\hline Latvia & 7.3 & 8.2 & 7.6 \\
\hline Lithuania & 6.3 & 6.6 & 7.1 \\
\hline Poland & 4.2 & 4.8 & 4.5 \\
\hline Slovakia & 3.9 & 3.6 & 3.7 \\
\hline Slovenia & 3.8 & 3.3 & 2.6 \\
\hline CEE 8 & 4.0 & 4.2 & 4.3 \\
\hline Austria & 2.0 & 1.7 & 1.3 \\
\hline Belgium & 1.9 & 1.3 & 1.7 \\
\hline Denmark & 1.7 & 1.5 & 1.0 \\
\hline Finland & 3.4 & 2.3 & 3.0 \\
\hline France & 1.8 & 1.2 & 1.8 \\
\hline Germany & 1.2 & 0.9 & 1.0 \\
\hline Greece & 3.6 & 2.5 & 2.7 \\
\hline Ireland & 6.0 & 3.6 & 4.2 \\
\hline Italy & 1.3 & 0.3 & 1.7 \\
\hline Luxemburg & 3.9 & 3.4 & 2.6 \\
\hline Netherlands & 1.7 & 0.7 & 1.8 \\
\hline Portugal & 1.8 & 0.2 & 2.1 \\
\hline Spain & 2.8 & -0.2 & 2.9 \\
\hline Sweden & 2.4 & 2.0 & 2.1 \\
\hline UK & 2.5 & 1.7 & 3.2 \\
\hline EU 15 & 1.8 & 0.9 & 1.9 \\
\hline
\end{tabular}


Revised in February, 2006

Table 4

\section{Electoral dismissals}

\begin{tabular}{lccc}
\hline \hline Country & $\begin{array}{c}\text { Elections } \\
1989-2004\end{array}$ & $\begin{array}{c}\text { "Electoral } \\
\text { dismissals" }\end{array}$ & Year $(s)$ of dismissal $(s)$ \\
\hline Czech Republic & 5 & 3 & $1990,1992,1998$ \\
Estonia & 5 & 4 & $1990,1995,1999,2003$ \\
Hungary & 4 & 4 & $1990,1994,1998,2002$ \\
Latvia & 5 & 4 & $1990,1995,1998,2002$ \\
Lithuania & 5 & 4 & $1990,1993,1996,2000$ \\
Poland & 4 & 4 & $1991,1993,1997,2001$ \\
Slovakia & 5 & 4 & $1990,1992,1994,1998$ \\
Slovenia & 5 & 3 & $1990,1993,2004$ \\
CEE 8 & 38 & 30 & \\
\hline
\end{tabular}

Note: "Electoral dismissal" occurs when there is (i) a major rearrangement of the governing coalition following elections, including (ii) the change in the government leadership and (iii) some shift in policy priorities; see the full explanation at the following website of Zdenek Kudrna <ies.fsv.cuni.cz/ kudrna/MemoTable4.pdf>.

Source: Compiled on the basis of the Economist Intelligence Unit - Country reports at <www.eiu.com>. 


\section{Comparison of characteristics}

\begin{tabular}{|c|c|c|c|c|c|c|c|}
\hline & & CEE region & $\begin{array}{c}\text { A. } \\
\text { Transformation } \\
\text { of the Soviet } \\
\text { Union from } \\
\text { capitalism into } \\
\text { socialism }\end{array}$ & $\begin{array}{c}\text { B. } \\
\text { Hungary: } \\
\text { Horthy } \\
\text { restoration } \\
\text { Chile: } \\
\text { Pinochet } \\
\text { restoration }\end{array}$ & $\begin{array}{c}\text { C. } \\
\text { China: } \\
\text { Transformation } \\
\text { after Mao }\end{array}$ & $\begin{array}{c}D . \\
\text { West Germany: } \\
\text { Transformation } \\
\text { after WW2 }\end{array}$ & $\begin{array}{c}E . \\
\text { The great } \\
\text { historical } \\
\text { transformation in } \\
\text { Europe: from the } \\
\text { Middle Ages into } \\
\text { Modernity, from } \\
\text { pre-capitalism } \\
\text { into capitalism }\end{array}$ \\
\hline \multicolumn{8}{|c|}{ Characteristics } \\
\hline 1 & $\begin{array}{l}\text { In the main direction of the } \\
\text { development of the economic system? }\end{array}$ & Yes & No & Yes & Yes & Yes & Yes \\
\hline 2 & $\begin{array}{l}\text { In the main direction of the } \\
\text { development of the political system? }\end{array}$ & Yes & No & No & No & Yes & Yes \\
\hline 3 & Parallel in all spheres? & Yes & Yes & Yes & No & No & $\begin{array}{c}\text { Yes } \\
\text { (with time lags) }\end{array}$ \\
\hline 4 & Without violence? & Yes & No & No & Yes & No & No \\
\hline 5 & Without foreign military occupation? & Yes & Yes & Yes & Yes & No & No \\
\hline & Fast? & Yes & Yes & Yes & No & Yes & $\begin{array}{c}\text { No } \\
\text { (very long period) }\end{array}$ \\
\hline
\end{tabular}


Revised in February, 2006

Table 6

Distribution of income: Gini coefficient

\begin{tabular}{lcccc}
\hline \hline & $\begin{array}{c}\text { Pre-transition } \\
\text { Country }\end{array}$ & $\begin{array}{c}\text { Mid-transition } \\
\text { 1987-1989 }\end{array}$ & $\begin{array}{c}\text { Post-transition } \\
\text { Percentage change from }\end{array}$ & $\begin{array}{c}\text { Per-1997 } \\
\text { pre-to post-transition }\end{array}$ \\
\hline Czech Republic & 19.8 & 23.9 & 23.4 & 18 \\
Estonia & 28.0 & 36.1 & 39.3 & 40 \\
Hungary & 22.5 & 25.4 & 26.7 & 19 \\
Latvia & 26.0 & 32.6 & 35.8 & 38 \\
Lithuania & 26.3 & 30.9 & 35.7 & 36 \\
Poland & 27.5 & 33.4 & 35.3 & 28 \\
Slovakia & 19.4 & 24.9 & 26.7 & 38 \\
Slovenia & 21.0 & 24.0 & 24.4 & 16 \\
CEE 8 & 23.8 & 28.9 & 30.9 & 29 \\
EU 15 & 26.9 & 27.8 & 28.6 & 7 \\
\hline
\end{tabular}

Notes: The Gini coefficient is a measure of the degree of inequality in the distribution of income. It is equal to " 0 " in the case of total income equality (everyone receives the same income) and to "100" in the case of total inequality (one household receives all the income). In this table estimates are based on interpolated distributions from grouped data from various household budget surveys. Survey coverage may vary over time. Data refer to the distribution of individuals according to household per capita income. Five data points for the EU average are not available - Belgium (2), Spain (2) and Portugal (1).

Sources: CEE 8 data from various sources compiled for the UNICEF IRC TransMONEE 2004 Database. EU 15 data: OECD Society at a Glance: OECD Social indicators 2005 and the World Bank World Development Indicators 2005. 
Table 7

Consumption inequality

\begin{tabular}{|c|c|c|c|c|c|c|c|}
\hline \multirow[b]{3}{*}{ Country } & \multirow[b]{3}{*}{ Survey year } & \multicolumn{4}{|c|}{ Share of income or consumption } & \multirow{3}{*}{$\begin{array}{c}\text { Richest } \\
10 \% \text { to } \\
\text { poorest } \\
10 \%\end{array}$} & \multirow{3}{*}{$\begin{array}{c}\text { Richest } \\
20 \% \text { to } \\
\text { poorest } \\
20 \% \\
\end{array}$} \\
\hline & & \multicolumn{4}{|c|}{$($ percent $)$} & & \\
\hline & & Poorest $10 \%$ & Poorest $20 \%$ & Richest $20 \%$ & Richest $10 \%$ & & \\
\hline Czech Republic & 1996 & 4.3 & 10.3 & 35.9 & 22.4 & 5.2 & 3.5 \\
\hline Estonia & 2000 & 1.9 & 6.1 & 44 & 28.5 & 14.9 & 7.2 \\
\hline Hungary & 1999 & 2.6 & 7.7 & 37.5 & 22.8 & 8.9 & 4.9 \\
\hline Latvia & 1998 & 2.9 & 7.6 & 40.3 & 25.9 & 8.9 & 5.3 \\
\hline Lithuania & 2000 & 3.2 & 7.9 & 40 & 24.9 & 7.9 & 5.1 \\
\hline Poland & 1999 & 2.9 & 7.3 & 42.5 & 27.4 & 9.3 & 5.8 \\
\hline Slovakia & 1996 & 3.1 & 8.8 & 34.8 & 20.9 & 6.7 & 4 \\
\hline Slovenia & 1998/99 & 3.6 & 9.1 & 35.7 & 21.4 & 5.9 & 3.9 \\
\hline CEE 8 & $1996-2000$ & 3.1 & 8.1 & 39.5 & 24.9 & 8.2 & 5.0 \\
\hline$E U 15$ & $1994-2000$ & 2.7 & 7.4 & 40.2 & 25.1 & 9.6 & 5.6 \\
\hline
\end{tabular}

Source: UN Human Development Report 2004 database. 
Table 8

\section{Total employment}

\begin{tabular}{lcccccccc}
\hline \hline & & \multicolumn{7}{c}{$(\mathbf{1 9 8 9}=\mathbf{1 0 0})$} \\
Country & 1990 & 1991 & 1992 & 1993 & 1996 & 1999 & 2002 & 2003 \\
\hline Czech Republic & 99.1 & 93.6 & 91.2 & 89.8 & 93.5 & 88.2 & 88.0 & 87.4 \\
Estonia & 98.6 & 96.3 & 90.9 & 83.5 & 74.0 & 69.2 & 70.0 & 71.0 \\
Hungary & 96.7 & 86.7 & 78.1 & 73.1 & 69.8 & 72.9 & 74.1 & 75.1 \\
Latvia & 100.1 & 99.3 & 92.1 & 85.7 & 72.4 & 73.9 & 75.4 & 76.8 \\
Lithuania & 97.3 & 99.6 & 97.4 & 93.4 & 87.0 & 85.0 & 82.0 & 83.9 \\
Poland & 95.8 & 90.1 & 86.4 & 84.3 & 88.3 & 90.4 & 85.8 & 85.2 \\
Slovakia & 98.2 & 85.9 & 86.9 & 84.6 & 85.5 & 82.3 & 82.1 & 83.6 \\
Slovenia & 96.1 & 88.6 & 83.7 & 81.3 & 78.7 & 80.1 & 82.8 & 82.1 \\
CEE 8 & 96.9 & 90.9 & 87.0 & 84.2 & 85.5 & 85.8 & 83.5 & $\mathbf{8 3 . 4}$ \\
EU 15 & 101.8 & 102.3 & 101.1 & 99.6 & 100.7 & 105.2 & 109.2 & $\mathbf{1 0 9 . 5}$ \\
\hline
\end{tabular}

Source: UN ECE Economic Survey of Europe 2005, n. 1, p. 125. 
Revised in February, 2006

Table 9

\section{Unemployment rates}

\begin{tabular}{|c|c|c|c|c|c|c|c|}
\hline \multirow[b]{2}{*}{ Country } & \multicolumn{7}{|c|}{ (percent of labor force) } \\
\hline & 1990 & 1992 & 1993 & 1996 & 1999 & 2002 & 2003 \\
\hline Czech Republic & 0.7 & 2.6 & 3.5 & 3.5 & 9.4 & 9.8 & 10.3 \\
\hline Estonia & .. & 1.6 & 5.0 & 5.6 & 6.7 & 6.8 & 6.1 \\
\hline Hungary & 1.7 & 12.3 & 12.1 & 10.5 & 9.6 & 8.0 & 8.4 \\
\hline Latvia & .. & 2.3 & 5.8 & 7.2 & 9.1 & 8.5 & 8.6 \\
\hline Lithuania & .. & 3.5 & 3.4 & 6.2 & 10.0 & 10.9 & 9.8 \\
\hline Poland & 6.5 & 14.3 & 16.4 & 13.2 & 13.1 & 20.0 & 20.0 \\
\hline Slovakia & 1.6 & 10.4 & 14.4 & 12.8 & 19.2 & 17.4 & 15.6 \\
\hline Slovenia & .. & 13.3 & 15.5 & 14.4 & 13.0 & 11.3 & 11.0 \\
\hline CEE 8 & 4.4 & 10.6 & 12.4 & 10.6 & 12.1 & 15.4 & 15.3 \\
\hline$E U 15$ & 7.3 & 8.7 & 10.0 & 10.2 & 8.7 & 7.7 & 8.1 \\
\hline
\end{tabular}

Note: Figures for Estonia are only job seekers until 1999.

Sources: Registered unemployment rates for CEE8 from the UN ECE Economic Survey of Europe 2004, n.2, p. 85; Standardized unemployment rates for the EU-15 from UN ECE Economic Survey of Europe 2005, n.1, p. 126. 
Table 10

\section{Crime rates}

\begin{tabular}{|c|c|c|c|c|}
\hline \multirow[b]{2}{*}{ Country } & \multicolumn{4}{|c|}{$(1989=100)$} \\
\hline & 1990 & 1994 & 1998 & 2002 \\
\hline Czech Republic & 180 & 309 & 355 & 313 \\
\hline Estonia & 124 & 200 & 270 & 321 \\
\hline Hungary & 153 & 175 & 272 & 193 \\
\hline Latvia & 117 & 146 & 137 & 190 \\
\hline Lithuania & 118 & 189 & 260 & 247 \\
\hline Poland & 161 & 163 & 192 & 253 \\
\hline Slovakia & 150 & 293 & 198 & 227 \\
\hline Slovenia & 96 & 110 & 139 & 193 \\
\hline CEE 8 & 156 & 194 & 228 & 249 \\
\hline
\end{tabular}

Note: Crime data cover reported and registered crime only. Crime rates are subject to varying national legislation.

Source: UNICEF IRC TransMONEE 2004 Database. 
Revised in February, 2006

Table 11

Confidence in Parliament and other institutions

\begin{tabular}{|c|c|c|c|}
\hline & Parliament & $\begin{array}{c}\text { Civil } \\
\text { Service }\end{array}$ & $\begin{array}{l}\text { Education } \\
\text { system }\end{array}$ \\
\hline & \multicolumn{3}{|c|}{ (percentage having confidence in) } \\
\hline Czech Republic & 12.2 & 21.8 & 54.6 \\
\hline Estonia & 27.0 & 40.4 & 73.9 \\
\hline Hungary & 34.0 & 49.6 & 64.3 \\
\hline Latvia & 27.5 & 49.2 & 73.7 \\
\hline Lithuania & 10.6 & 20.6 & 66.6 \\
\hline Poland & 32.8 & 32.6 & 81.2 \\
\hline Slovakia & 42.8 & 38.7 & 76.3 \\
\hline Slovenia & 25.3 & 25.3 & 80.3 \\
\hline CEE 8 & 29.3 & 33.8 & 73.7 \\
\hline Austria & 40.7 & 42.4 & 86.2 \\
\hline Belgium & 39.1 & 46.1 & 77.9 \\
\hline Denmark & 48.6 & 54.9 & 75.0 \\
\hline Finland & 43.7 & 40.9 & 88.8 \\
\hline France & 40.6 & 45.9 & 68.4 \\
\hline Germany & 35.7 & 38.7 & 72.6 \\
\hline Greece & 29.0 & 20.2 & 37.0 \\
\hline Ireland & 31.1 & 59.3 & 86.4 \\
\hline Italy & 34.1 & 33.2 & 53.2 \\
\hline Luxemburg & 62.7 & 59.5 & 67.8 \\
\hline Netherlands & 55.3 & 37.5 & 73.1 \\
\hline Portugal & 49.2 & 53.6 & 59.8 \\
\hline Spain & 46.4 & 40.5 & 67.6 \\
\hline Sweden & 51.1 & 48.8 & 67.8 \\
\hline UK & 35.5 & 45.9 & 66.3 \\
\hline$E U 15$ & 39.1 & 41.1 & 66.8 \\
\hline
\end{tabular}

Note: The respondents were asked to answer the following question: "Tell me, for each item listed, how much confidence you have in them; is it a great deal, quite a lot, not very much, or none at all?" Those answering "a great deal" and "quite a lot" were counted as having confidence.

Source: Halman (2001, pp. 187, 192. and 192). 
Revised in February, 2006

Table 12

Life-time satisfaction

\begin{tabular}{|c|c|c|c|}
\hline \multirow[b]{2}{*}{ Country } & $1990-1993$ & 1995-97 & 1999-2002 \\
\hline & \multicolumn{3}{|c|}{ (average on a scale from 1 to 10 ) } \\
\hline Czech Republic & 6.37 & .. & 7.06 \\
\hline Estonia & 6.00 & 5.00 & 5.93 \\
\hline Hungary & 6.03 & .. & 5.80 \\
\hline Latvia & 5.70 & 4.90 & 5.27 \\
\hline Lithuania & 6.01 & 4.99 & 5.20 \\
\hline Poland & 6.64 & 6.42 & 6.20 \\
\hline Slovakia & 6.15 & .. & 6.03 \\
\hline Slovenia & 6.29 & 6.46 & 7.23 \\
\hline CEE 8 & 6.40 & 6.20 & 6.20 \\
\hline Austria & 6.51 & .. & 8.03 \\
\hline Belgium & 7.60 & 7.93 & 7.43 \\
\hline Denmark & 8.16 & .. & 8.24 \\
\hline Finland & 7.68 & 7.78 & 7.87 \\
\hline France & 6.78 & .. & 7.01 \\
\hline Germany & 7.22 & 7.22 & 7.42 \\
\hline Greece & .. & .. & 6.67 \\
\hline Ireland & 7.88 & .. & 8.20 \\
\hline Italy & 7.30 & .. & 7.17 \\
\hline Luxemburg & .. & .. & 7.81 \\
\hline Netherlands & 7.77 & .. & 7.85 \\
\hline Portugal & 7.07 & .. & 7.04 \\
\hline Spain & 7.15 & 6.61 & 7.03 \\
\hline Sweden & 7.97 & 7.77 & 7.64 \\
\hline UK & 7.49 & 7.46 & 7.40 \\
\hline$E U 15$ & 7.26 & 7.24 & 7.30 \\
\hline \multicolumn{4}{|c|}{$\begin{array}{l}\text { Sources: World Values Survey and European Values Survey; see the following website } \\
\text { <www.worldvaluessurvey.com>. Sanfey and Teksoz (2005) are using these data to study life satisfaction } \\
\text { in post-socialist countries. The table reporting the summary data for the EU- } 8 \text { countries is on p. } 17 \text { of } \\
\text { their paper. I am grateful to Peter Sanfey and Utku Teksos (EBRD), who provided the complementary } \\
\text { data for the EU-15 countries and the data for region-averages in direct communication. }\end{array}$} \\
\hline
\end{tabular}


Table 13

\section{Life-time satisfaction: distribution of responses}

\begin{tabular}{lcccc}
\hline \hline & $\begin{array}{c}\text { \% not at all } \\
\text { satisfied }\end{array}$ & $\begin{array}{c}\text { \% not very } \\
\text { satisfied } \\
\text { (percentage of answers) }\end{array}$ & $\begin{array}{c}\text { \% fairly } \\
\text { satisfied }\end{array}$ & $\begin{array}{c}\text { \% very } \\
\text { satisfied }\end{array}$ \\
\hline Country & 5 & 26 & 57 & 10 \\
Estonia & 11 & 35 & 47 & 6 \\
Hungary & 11 & 34 & 45 & 9 \\
Latvia & 8 & 35 & 49 & 6 \\
Lithuania & 10 & 32 & 51 & 5 \\
Poland & 9 & 28 & 50 & 11 \\
Slovakia & 13 & 33 & 48 & 6 \\
Slovenia & 2 & 12 & 65 & $\mathbf{1 0}$ \\
CEE 8 & $\mathbf{9}$ & $\mathbf{2 9}$ & $\mathbf{5 0}$ & $\mathbf{1 9}$ \\
EU 15 & $\mathbf{4}$ & $\mathbf{1 7}$ & $\mathbf{6 0}$ &
\end{tabular}

Note: The respondents were asked the following question: "On the whole, how are you satisfied with your life in general? Would you say you are...?"

Source: Eurobarometer Public Opinion in the Candidate Countries survey conducted in OctoberNovember 2003; see the following website <europe.eu.int./comm/public_opinion>. 
Revised in February, 2006

Table 14

Attitudes to regime: old, new, and future

\begin{tabular}{|c|c|c|c|}
\hline & Old regime & Current & In five years \\
\hline Country & \multicolumn{3}{|c|}{ (percentage of positive answers) } \\
\hline Czech Republic & 32 & 69 & 82 \\
\hline Estonia & 55 & 75 & 79 \\
\hline Hungary & 58 & 64 & 81 \\
\hline Latvia & 50 & 51 & 71 \\
\hline Lithuania & 59 & 70 & 84 \\
\hline Poland & 51 & 51 & 67 \\
\hline Slovakia & 51 & 51 & 65 \\
\hline Slovenia & 68 & 69 & 74 \\
\hline CEE 8 & 50 & 57 & 72 \\
\hline
\end{tabular}

Note: The respondents were asked the following question: "Here is a scale for ranking how our system of government works. The top, plus 100, is the best; the bottom, minus 100, the worst. Where on this scale would you put the former Communist regime / our current system of governing with free elections and many parties / our system of governing five years in the future?"

Source: Rose (2005, p. 17). 
Revised in February, 2006

Table 15

\section{Historical comparison with Austria}

\begin{tabular}{lccccccc}
\hline \hline Country & 1870 & 1913 & $\begin{array}{c}1937 \\
\text { (Austria's }\end{array}$ & $\begin{array}{c}1950 \\
\text { GPP per capita = 100) }\end{array}$ & 1980 & 1989 & 2000 \\
\hline Czechoslovakia & $62 \%$ & $60 \%$ & $91 \%$ & $94 \%$ & $58 \%$ & $54 \%$ & $43 \%$ \\
Hungary & $59 \%$ & $61 \%$ & $81 \%$ & $67 \%$ & $46 \%$ & $42 \%$ & $36 \%$ \\
Poland & $51 \%$ & $50 \%$ & $61 \%$ & $66 \%$ & $42 \%$ & $35 \%$ & $36 \%$ \\
\hline
\end{tabular}

Note: Czechoslovakia in 2000 is weighted average of the Czech and Slovak Republics.

Source: Calculated from the OECD database accompanying Maddison (2003). 
Table 16

Convergence times to Western Europe

To EU $14100 \%$

Country

Czech Republic

Estonia

Hungary

Latvia

Note: $\mathbf{E}$ assumptic

Source: Wagner and Hlouskova (2005, p. 367).
To EU $1480 \%$

(years)

38

21

60

45

46

31

74

59

68

52

72

55

48

33

30

9

55

38

1

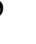

Lithuania

Poland

Slovakia

Slovenia

CEE 8

55


Revised in February, 2006

Table 17

\section{Endorsement of undemocratic alternatives}

\begin{tabular}{lccc}
\hline \hline & Communist & Army & Dictator \\
& & (percent regarding as better) & \\
\hline Czech Republic & 18 & 1 & 13 \\
Estonia & 8 & 2 & 40 \\
Hungary & 17 & 2 & 17 \\
Latvia & 7 & 4 & 38 \\
Lithuania & 14 & 5 & 40 \\
Poland & 23 & 6 & 33 \\
Slovakia & 30 & 3 & 25 \\
Slovenia & 23 & 6 & 27 \\
CEE 8 & 21 & 4 & 29 \\
\hline Note: The respondents & & 5 & \\
\hline
\end{tabular}

Note: The respondents were asked the following: "Our present system of government is not the only one that this country had. Some people say that we would be better off if the country was governed differently. What do you think? We should return to Communist rule. The army should govern the country. Best to have a strong leader who can quickly decide everything."

Source: Rose (2002, p. 10). 


\section{REFERENCES $^{17}$}

Bloch, M. (1989) [1939] Feudal Society (London: Routledge)

Braudel, F. (1972-1973) [1949] The Mediterranean and the Mediterranean World in the Age of Philip II (New York: Harper and Row)

Braudel, F. (1992) [1969-1979] Civilization and Capitalism, 15th-18th century. I-III.; I. The Structures of Everyday Life; II. The Wheels of Commerce; III. The Perspective of the World (Berkeley: University of California Press)

Brenner, R. (1976) 'Agrarian Class Structure and Economic Development in Pre-Industrial Europe', Past and Present, 70, pp. 30-75

Burke, P. (1990) 'Interview Conducted by Karl Vocelka and Markus Reisenleitner' http://www.univie.ac.at/Neuzeit/gburke.htm

Campos, N. F. and Coricelli, F. (2002) 'Growth in Transition: What We Know, What We Don't, and What We Should', Journal of Economic Literature, 40(3) (September), pp. 793-836

Csaba, L. (2005) The New Political Economy of Emerging Europe (Budapest: Akadémiai)

Dahl, R. A. (1971) Polyarchy: Participation and Opposition (New Haven: Yale University Press)

European Bank for Reconstruction and Development (2002) Transition Report (London: EBRD)

European Commission (2003) Comprehensive Monitoring Report of the European Commission of 5 November 2003 on the State of Preparedness for EU Membership of the Czech Republic, Estonia, Cyprus, Latvia, Lithuania, Hungary, Malta, Poland, Slovenia and Slovakia, 675 final (Brussels: European Union)

Haggard, S. and Kaufman, R. R. (2005) The Political Economy of Democratic Transitions (Princeton: Princeton University Press)

Hayek, F. von (1944) Road to Serfdom (Chicago: University of Chicago Press)

Halman, L. (2001) The European Values Study: A Third Wave, Tilburg: EVS, WORC, pp. 170

Hirschman, A. O. (1982) Shifting Involvements (Princeton: Princeton University Press)

Huntington, S. P. (1991) The Third Wave: Democratization in the Late Twentieth Century (Norman: University of Oklahoma Press)

Karamzin, N. M. (2003) [1789-1790] Letters of a Russian Traveller (Oxford: Voltaire Foundation)

Klaniczay, G. (2001) 'The Middle Ages' in Smelser, N. J. and Baltes, P. B. (ed.) International Encyclopaedia of the Social \& Behavioral Sciences (Amsterdam: Elsvier)

Kolodko, G. (2000) From Shock to Therapy: The Political Economy of Post-socialist Transformation (Oxford: Oxford University Press)

Kornai, J. (1980) Economics of Shortage (Amsterdam, New York: North-Holland Pub. Co.).

Kornai, J. (1992) The Socialist System (Princeton - Oxford: Princeton University Press - Oxford University Press)

Kornai, J. (1998) From Socialism to Capitalism: What is Meant by the 'Change of System' (London: Social Market Foundation)

Kornai, J. (2000) 'Ten Years After 'The Road to a Free Economy', The Author Self-Evaluation', in Pleskovic, B. and Stern, N. (ed.), Annual World Bank Conference on Development Economics 2000 (Washington, DC: The World Bank)

Le Goff, J. (1982) [1977] Time, Work, \& Culture in the Middle Ages (Chicago: University of Chicago Press)

Maddison, A. (2003) The World Economy: Historical Statistics (Paris: OECD, Development Centre Studies)

McFaul, M. (2002) 'The Fourth Wave of Democracy and Dictatorship', World Politics, 54, pp. 212-244.

O'Donnell, G. A., Schmitter P. C. and Whitehead, L. (1988) Transitions from Authoritarian Rule: Comparative Perspectives (Baltimore: Johns Hopkins University Press)

Offe, C. (1996) Varieties of Transition: the East European and East German Experience (Cambridge, MA: Polity Press)

Pirenne, H. (1937) [1933] Economic and Social History of Medieval Europe, (New York: Harcourt, Brace and World Inc.)

Polányi, K. (1962) [1944] The Great Transformation: The Political and Economic Origins of Our Time (Boston: Beacon Paperback)

Przeworski, A. (1991) Democracy and the Market (Cambridge: Cambridge University Press) 
Raeds, P. (2001) 'When Were the Middle Ages?' in Sogner, S. (ed.), Making Sense of Global History, The 19th International Congress of the Historical Sciences Oslo 2000 Commemorative Volume (Oslo)

Roland, G. (2000) Transition and Economics: Politics, Markets, and Firms (Cambridge, Mass: MIT Press)

Rose, R. (2002) A Bottom Up Evaluation of Enlargement Countries: New Europe Barometer 1 (Glasgow: Centre for the Study of Public Policy)

Rose, R. (2005) Insiders and Outsiders: New Europe Barometer 2004 (Glasgow: Centre for the Study of Public Policy)

Rose-Ackerman, S. (2005) From Elections to Democracy (Cambridge: Cambridge University Press)

Ruesschemeyer, D., Stephens, E. H. and Stephens, J. D. (1992) Capitalist Development and Democracy (Cambridge: Polity Press)

Sanfey, P. and Teksoz, U. (2005) 'Does Transition Make You Happy?' EBRD Working Paper No. 91 (London: European Bank for Reconstruction and Development)

Schmitter, P. C. and Karl, T. L. (1991) 'What Democracy Is ... And Is Not', Journal of Democracy, 2(3), pp. 76-88

Schumpeter, J. (1942) Capitalism, Socialism and Democracy (New York: Harper and Brothers)

Stiglitz, J. (1999) 'Whither Reform?' Annual Bank Conference on Development Economics (Washington, DC: World Bank)

Svejnar, J. (2002) 'Transition Economies: Performance and Challenges', The Journal of Economic Perspectives, 16(1) (Winter), pp. 3-28

Tilly, C. (1984) Big Structures, Large Processes, Huge Comparisons, New York: Russel Sage Foundation

Tóth, I. Gy. (2004) 'Income composition and inequalities 1987-2003' in Kolosi, T., Tóth, I. Gy. and Vukovich, Gy. (ed.) Social Report 2004 (Budapest: TÁRKI)

Usher, D. (1981) The Economic Preriquisite to Democracy (Oxford: Basil Blackwell)

Wagner, M. and Hlouskova, J. (2005) 'CEEC Growth Projections: Certainly Necessary and Necessarily Uncertain', Economics of Transition, 13(2), pp. 341-372

Wallerstein, I. (1974) The Modern World-System: Capitalist Agriculture and the Origins of the European World-Economy in the Sixteenth Century (New York: Academic Press)

Wallerstein, I. (1979) The Capitalist World-Economy (Cambridge: Cambridge University Press) 